Ilona Kulak

Uniwersytet Jagielloński

\title{
MOTYWY RELIGIJNE I MAGICZNE \\ UTRWALONE W LUDOWYCH NAZWACH ROŚLIN \\ (NA PRZYKLADZIE LEKSYKI GÓRALI RABCZAŃSKICH)
}

Z życiem społeczności wiejskich ściśle związana była - i nadal jest - religijność, nakazy oraz zakazy kościelne sprzyjały bowiem utrzymaniu danego porządku rzeczy. Obok wierzeń i praktyk religijnych trwały również wierzenia i praktyki magiczne - jako jeden ze sposobów ustanawiania rzeczywistości ${ }^{1}$. Chrześcijaństwo nigdy jednak nie akceptowało tak fascynujących ludzi zabiegów magicznych, które - dzięki znajomości zaklęć - dawały możliwość wpływania na własny i cudzy los. Religia starała się magię wykorzenić i wprowadzić religijny obraz świata, gdzie los ludzki i siły przyrody były poddane jedynie woli bożej² ${ }^{2}$ Przenikanie się pierwiastka chrześcijańskiego i pogańskiego w kulturze ludowej oddaje język, w który wpisane zostały dawne tradycje. Utrwalają je m.in. ludowe nazwy roślin-zwierciadło wierzeń, zwyczajów czy obrzędów, zarówno religijnych, jak i magicznych.

W dotychczasowych opracowaniach językoznawczych można odnaleźć liczne teksty poświęcone gwarowemu słownictwu roślinnemu, m.in. publikacje Wandy Budziszewskiej ${ }^{3}$, Haliny Pelcowej ${ }^{4}$ czy Jadwigi Waniakowej ${ }^{5}$. Pojawiły

${ }^{1}$ Z. Mach, Obecność magii (recenzja), w: D. Jaźwiecka-Bujalska, Między magia a religia, czyli zabobony i przesądy wśród duchowieństwa katolickiego we współczesnej Polsce, Kraków 2000, s. 8.

2 Tamże, s. 7-8.

${ }^{3}$ Por. m.in. W. Budziszewska, Stowiańskie słownictwo dotyczace przyrody żywej, Wrocław 1965; taż, Wybrane nazwy roślin ze Szczawnicy i okolic, „Język Polski” 1985 , z. 2-3, s. 158-162; taż, Pierwiastek chrześcijański i pogański w polskiej terminologii botanicznej na tle słowiańskim, „Rozprawy Komisji Językowej Łódzkiego Towarzystwa Naukowego" 1986, t. 32, s. 31-37.

${ }^{4}$ Por. m.in. H. Pelcowa, Nazwy roślin w świadomości językowej ludności wiejskiej, w: „Język a Kultura”, t. 16: Świat roślin w języku i kulturze, red. A. Dąbrowska i I. Kamińska-Szmaj, Wrocław 2000, s. 99-116; taż, Językowy obraz roślin w gwarach Lubelszczyzny, w: Język polski. Współczesność. Historia, red. W. Książek-Bryłowa i H. Duda, Lublin 2002, t. 3, s. 127-144.

${ }^{5}$ Por. m.in. J. Waniakowa, Polskie gwarowe nazwy dziko rosnacych roślin zielnych na tle słowiańskim. Zagadnienia ogólne, Kraków 2012. 
się także prace dotyczące nazw utrwalających w swej strukturze sakronimy bądź odwołujących się do wierzeń, przesądów czy uroków, np. artykuły Stanisławy Niebrzegowskiej-Bartmińskiej ${ }^{6}$, Macieja Raka ${ }^{7}$, Ewy Rogowskiej-Cybulskiej ${ }^{8}$, Agnieszki Wierzbickiej ${ }^{9}$. Badania nad słownictwem roślinnym prowadzone są na wielu płaszczyznach, przy wykorzystaniu różnych metodologii, choć szczególne znaczenie dla niniejszego tekstu mają opracowania, których autorzy dążą do ujawnienia sposobu kategoryzowania rzeczywistości przez wiejską wspólnotę językowo-kulturową ${ }^{10}$. Zgromadzone nazwy poddawane są jednak głównie analizie semantycznej, rzadziej analizie ilościowej.

Celem artykułu jest próba określenia liczby gwarowych nazw roślin motywowanych skojarzeniami religijnymi oraz magicznymi na tle całego odnotowanego zasobu ludowej leksyki botanicznej. Zbiór ten obejmuje także nazwy gwarowe odzwierciedlające w swojej strukturze semantycznej właściwości fizyczne rośliny, miejsce występowania, pochodzenie czy praktyczne wykorzystanie gatunku ${ }^{11}$. Analiza prowadzić ma również do odtworzenia ludowej wizji świata, sposobu myślenia społeczności wiejskiej utrwalonych w ludowych nazwach roślin, na których powstanie rzutowały tradycje dawnej kultury - religia i magia. Ponadto $\mathrm{w}$ artykule poszukiwano odpowiedzi na pytanie o relacje między pierwiastkiem chrześcijańskim a pogańskim w kulturze ludowej. Język utrwala bowiem wyrosły z określonej praktyki społecznej zbiór doświadczeń danej wspólnoty, jest swego rodzaju magazynem informacji o rzeczywistości, wypełnianym w ciągu wielu pokoleń ${ }^{12}$.

Materiał - ludowe nazwy roślin - zebrano w latach 2013-2014 podczas nieoficjalnych rozmów z mieszkańcami kilku wsi w południowo-zachodniej

${ }^{6}$ S. Niebrzegowska-Bartmińska, Sakronimy w polskim ludowym obrazie ziól, w: W'świecie nazw. Księga jubileuszowa dedykowana Profesorowi Czesławowi Kosylowi, red. H. Pelcowa, Lublin 2010, s. 277-289.

${ }^{7}$ M. Rak, Kwiatki Matki Bożej. Góralskie fitonimy odwotujące się do świętych i Matki Bożej, w: Turystyka religijna na obszarach górskich, red. A. Jackowski, F. Mróz, I. Hodorowicz, Nowy Targ 2009, s. 447-457.

${ }^{8}$ E. Rogowska-Cybulska, Nazwy roślin motywowane słownictwem religijnym w ,, Słowniku gwar kaszubskich” Bernarda Sychty, „,Rocznik Gdański” 2004, t. 64, z. 1/2, s. $125-135$.

${ }^{9}$ A. Wierzbicka, Magia, wierzenia a gwarowe określenia roślin, „Rozprawy Komisji Językowej Łódzkiego Towarzystwa Naukowego" 2012, t. 58, s. 363-372.

${ }^{10}$ Por. np. H. Pelcowa, Językowy obraz roślin..., s. 127-144.

${ }^{11}$ Tekst ma na celu jedynie zasygnalizowanie pewnych zagadnień związanych z ludowym nazewnictwem roślinnym. Uzyskanie pewniejszej odpowiedzi na pytanie o liczebność gwarowych nazw botanicznych motywowanych odniesieniami kulturowymi wymaga dalszych badań.

12 J. Anusiewicz, Lingwistyka kulturowa. Zarys problematyki, Wrocław 1995, s. 44. 
części województwa małopolskiego, w powiecie nowotarskim: w Bielance, Rokicinach Podhalańskich, Sieniawie, Skawie, Spytkowicach oraz Rabie Wy$\dot{z ̇ n e j}^{13}$. Miejscowości te są położone w małopolskim obszarze dialektalnym ${ }^{14}$, a charakterystyczna dla tego regionu jest gwara podhalańska. Jej odmienność od języka ogólnopolskiego oraz innych gwar przejawia się na płaszczyźnie fonetycznej i morfologicznej szczególnie w języku reprezentantów najstarszego pokolenia.

Ludowe określenia botaniczne oraz ich motywacje semantyczne podawane przez informatorów odnotowywano lub nagrywano. Zgromadzono 198 gwarowych nazw roślin określających 143 gatunki. Różnica między liczbą desygnatów a liczbą nazw wynika z przyjęcia przez użytkowników języka różnych punktów widzenia w procesie nominacji, por. dmuxåvíyc / måi / mlyc ${ }^{15}$ (mniszek pospolity, Taraxacum officinale) $)^{16}$; iadv́isḱi / iyśy•ńåk / murćin / mưrćińḱ / máixånki (aster gawędka, Aster amellus); źurav́iyc / kryf Xrystusa / źyle śf́íyntoiaiskíie (dziurawiec zwyczajny, Hypericum perforatum). W wypadku nazw złożonych, dwu- lub wieloelementowych, np. uzy Matḱi B"u osḱiyi (drżączka średnia, Briza media), lv́vie pasce (wyżlin większy, Antirrhinum majus), analizie podlegał wyłącznie człon, którego motywację semantyczną przedstawił respondent. Zgromadzona leksyka objęła nie tylko słownictwo dyferencyjne (lokalne oraz ogólnogwarowe), lecz także leksykę wspólną różnym odmianom polszczyzny ${ }^{17}$, zatem przynależną również gwarze.

Odnotowane słownictwo przyporządkowano do czterech nadrzędnych kategorii pojęciowych, takich jak cechy fizyczne desygnatu, czas i miejsce wegetacji, wartość użytkowa oraz odniesienia kulturowe (religia i magia). Niniejsze rozwiązanie wynika z przyjętego założenia, że człowiek, nazywając określony desygnat bądź objaśniając słownictwo zgodnie z istniejącym w danej społeczności językowo-kulturowej systemem wartości oraz obowiązującymi wierzeniami

${ }^{13}$ Mieszkanką niniejszej miejscowości jest pisząca te słowa; fakt ten znacznie ułatwił nawiązanie kontaktów z informatorami.

${ }^{14}$ S. Dubisz, H. Kraś, N. Kolis, Dialekty i gwary polskie, Warszawa 1995, s. 79.

${ }^{15} \mathrm{~W}$ artykule zastosowano uproszczony zapis fonetyczny. Nie zaznaczano dziąsłowości $(t, d \varphi)$ oraz fonetyki międzywyrazowej (np. cosnyg ńyźvíyźi zamiast cosnyg ńyźvíyźi). Nazwy własne zapisywano wielką literą (np. bućiḱi Matki B ${ }^{u}$ osḱkiyi).

${ }^{16}$ Polskie oraz łacińskie nazwy roślin ułatwiają rozpoznanie desygnatu. Identyfikacji dokonano na podstawie listy roślin naczyniowych Polski, zob. Z. Mirek, H. Piękoś-Mirkowa, A. Zając, M. Zając, Flowering Plants and Pteridophytes of Poland. A Checklist. Krytyczna lista roślin naczyniowych Polski, Kraków 2002.

${ }^{17}$ Termin zaczerpnięty od A. Markowskiego, zob. tegoż, Polszczyzna końca XX wieku, Warszawa 1992, s. 16. 
czy ogólną wiedzą, redukuje złożoność otaczającej go rzeczywistości ${ }^{18}$. Naiwna kategoryzacja porządkuje zatem ogrom świata, oswajając go zarazem ${ }^{19}$. Wyodrębnione grupy nazw mogą więc obrazować typowy dla społeczności wiejskiej sposób myślenia o świecie ${ }^{20}$.

W klasyfikacji wyrazów do wyodrębnionych grup nadrzędne było wyjaśnienie respondenta co do motywacji danej nazwy. W większości wypadków informatorzy odkrywali na nowo elementy, które stały się motywem pierwotnym w procesie nominacji, a zatem cechy roślin (np. barwa, kształt, zapach, smak), czas i miejsce wegetacji itd. Cechę danego gatunku dostrzegano przez jego nazwę, która - w wielu wypadkach - sięga początków języków słowiańskich ${ }^{21}$. Z motywacją właściwą (pierwotną) niejednokrotnie zbiegała się jednak etymologia ludowa, definiowana przez Witolda Cienkowskiego jako synchroniczna motywacja semantyczna - motywacja, jaką wyraz przybrał, funkcjonując w języku²2 . Objaśnianie nazw roślin prowadzi nie tylko do ujawnienia wpisanych w ich strukturę wyrazów oznaczających cechę, „która była uważana za podstawę nazwania [...], czyli była tzw. motywem pierwotnym"23, lecz także do pokazania sposobu myślenia oraz postrzegania otaczającej rzeczywistości ${ }^{24}$. Eksplikacje użytkowników języka są bowiem zależne od obowiązujących w danej wspólnocie językowo-kulturowej norm, systemu wartości, wierzeń czy przesądów, które za Haliną Kurek - nazwać można wspólną bazą doświadczeniową 25 .

Analiza zgromadzonego materiału wskazuje, że człowiek, nazywając rośliny, bierze przede wszystkim pod uwagę cechy fizyczne desygnatów - do niniejszej kategorii można włączyć niemal 70\% określeń (136 nazw). Motywem pierwotnym w procesie nominacji są: barwa, np. cyrńice (jeżyna krzewiasta, Rubus fruticosus), śive butki (tojad mocny, Aconitum firmum), kształt, np. k"ưñiki (tojad mocny, Aconitum firmum), klucyki (pierwiosnek wyniosły, Primula elatior; pierwiosnek lekarski, Primula veris), zapach, np. íapcovńik (pelargonia wonna, Pelargonium odoratissimum), śmíyrźyle (aksamitka wzniesiona, Tagetes erecta), smak, np. kapuśćura (szczaw zwyczajny, Rumex acetosa), g’ůrycka (goryczka kropkowana,

${ }^{18}$ Por. H. Kurek, Przemiany leksyki gwarowej na Podkarpaciu, Kraków 2003, s. 40; A. Piechnik, Wizerunek kobiety i mężczyzny w językowym obrazie świata ludności wiejskiej (na przykładzie gminy Zakliczyn nad Dunajcem), Kraków 2009, s. 33.

${ }^{19}$ Por. J. Bartmiński, Styl potoczny, w: Encyklopedia kultury polskiej XX wieku, red. tenże, t. 2: Współczesny język polski, Wrocław 1993, s. 127.

${ }^{20}$ Por. R. Tokarski, Słownictwo jako interpretacja świata, w: Encyklopedia kultury..., s. 354 .

${ }^{21}$ J. Waniakowa, Polskie gwarowe nazwy..., s. 115-116.

${ }^{22}$ W. Cienkowski, Teoria etymologii ludowej, Warszawa 1972, s. 66-67.

${ }^{23}$ M. Dokulil, Teoria derywacji, tłum. A. Bluszcz i J. Stachowski, Wrocław 1979, s. 149.

${ }^{24}$ Por. H. Pelcowa, Nazwy roślin w świadomości..., s. 99.

${ }^{25}$ H. Kurek, Przemiany leksyki gwarowej..., s. 41. 
Gentiana punctata), wrażenia dotykowe, np. aksamittki (aksamitka wzniesiona, Tagetes erecta; aksamitka wąskolistna, Tagetes tenuifolia), $k^{u}$ oće uapḱi (kocanki piaskowe, Helichrysum arenarium; szarotka alpejska, Leontpodium alpinum), wydawany dźwięk, np. kšyiść / skšyp (skrzyp polny, Equisetum arvense), zjawiska ruchowe, np. p puvini / v́ilyc (powój polny, Convolvulus arvensis), "'uraźńik (niecierpek pospolity, Impatiens noli-tangere).

$\mathrm{Z}$ analizy zebranej leksyki wynika, że rzeczywistość pozajęzykowa jest odbierana głównie zmysłami. Dominującą rolę w percepcji odgrywa wzrok, jednak poznanie odbywa się także przez dotyk, węch, smak, sporadycznie słuch. Jak pisze Halina Kurek, ze zmysłowym postrzeganiem świata wiąże się swoisty dla społeczności wiejskiej typ racjonalności adaptacyjnej (instrumentalnej), opartej na konkretnym widzeniu otaczającej rzeczywistości ${ }^{26}$. Nominowane obiekty nie tylko mają sprecyzowaną barwę, kształt czy smak, lecz także rosną w określonym czasie oraz przestrzeni, mają uściślone znaczenie użytkowe. Nazwy związane z tymi czynnikami są również liczne - kategoria uwarunkowana czasem i miejscem wegetacji obejmuje 31 określeń (ok. 15,5\% zasobu), do kategorii nazw, które utrwalają wartość użytkową gatunków, wchodzą natomiast 34 nazwy (17\% ogółu). Użytkownik języka w akcie nominacji uwzględnia czas kwitnienia, np. iyśy•ńåk (aster gawędka, Aster amellus), mainovnicka (konwalijka dwulistna, Maianthemum bifolium), grudńåk (szlumbergera, Schlumbergera), owocowania, np. źimůfka ('odmiana jabłoni, Malus'), tudzież wysiewu desygnatów, np. i̇ažyc (jęczmień zwyczajny, Hordeum vulgare), ponadto miejsce ich występowania, np. $p^{u}$ odvưrńica (rdest ptasi, Polygonum aviculare), pšilascḱi (przylaszczka pospolita, Hepatica nobilis), czy pochodzenia, np. ${ }^{x}$ amerykůny (rącznik pospolity, Ricinus communis), krakovía áki (pelargonia rabatowa, Pelargonium zonale). Dla mieszkańców wsi znaczenie ma również wartość użytkowa określonych gatunków botanicznych, ich przydatność w gospodarstwie, np. jako pokarmu dla zwierząt, por. ḱniyubåśńik (lebiodka majeranek, Origanum majorana), śfínoxa (podagrycznik pospolity, Aegopodium podagraria), k"obylåk (szczaw lancetowaty, Rumex hydrolapatum), oraz możliwość zastosowania w medycynie ludowej, por. zrost (żywokost lekarski, Symphytum officinale), ayǵinka (pelargonia pachnąca, pelargonium graveolens). Pojawiły się również nazwy roślin uwydatniające szkodliwy czy zgubny wpływ na ludzi, np. kulibaba (widłak jałowcowaty, Lycopodium annotinum; widłak goździsty, Lycopodium clavatum), muordovńik (tojad mocny, Aconitum firmum), a nawet bezużyteczność, małą wartościowość z punktu widzenia mieszkańców, np. pựinka (jabłoń dzika, Malus sylvestris), pśưrka (bliźniczka psia trawka, Nardus stricte; jabłoń dzika, Malus sylvestris), pśå tråfka (rdest ptasi, Polygonum aviculare).

\footnotetext{
${ }^{26}$ Tamże, s. 46.
} 
Gwarowe nazwy roślin, których motywem pierwotnym była cecha fizyczna desygnatu, stanowią niewątpliwie najliczniejszą grupę zebranego słownictwa ludowego. Postrzeganie rzeczywistości i zarazem akt nominacji ukierunkowane są bowiem najczęściej na określony, wyrazisty element świata przyrody. W gwarowych nazwach botanicznych roślin nieczęsto ukazywana jest szersza perspektywa, „odniesienie do innego ważniejszego i znacznie większego obiektu”27.

Nazwy motywowane czynnikami kulturowymi (religią i magią) stanowią jedynie $9 \%$ zgromadzonej leksyki ${ }^{28}$. Do zbioru włączono 18 nazw ludowych (14 związanych z wiarą, 4 -z praktykami magicznymi) nadanych 17 desygnatom. Biorąc pod uwagę aspekt ilościowy, stwierdzić można, że pierwiastek chrześcijański i pogański rzadko odrywał rolę w procesie nadawania roślinom nazw. Akt nominacji był raczej ukierunkowany na wyróżniające się w porównaniu z innymi gatunkami cechy fizyczne desygnatu. Społeczność wiejska zwraca bowiem uwagę przede wszystkim na kształt, barwę rośliny, także jej zapach czy smak, miejsce występowania czy porę kwitnienia, jawiąc się tym samym jako baczny obserwator i interpretator przyrody, oczywiście na własny, naiwny sposób. Niekiedy użytkownik gwary w momencie tworzenia nazwy obejmował dany obiekt wraz z otaczającym go światem. Rzeczywistość zewnętrzna, w której mieści się desygnat, stawała się tym samym motywem pierwotnym ${ }^{29}$.

Właściwości fizyczne nominowanych desygnatów odzwierciedla także struktura części gwarowej leksyki botanicznej motywowanej względami kulturowymi. Większość kilkuelementowych nazw składa się z członu głównego oraz określającego. W członie głównym wyeksponowane zostało relacyjnie podobieństwo desygnatu do innego - znanego i bliskiego podmiotowi nominującemu - obiektu rzeczywistości pozajęzykowej, m.in. części ciała ludzkiego, np. $B^{u}$ oze licko

27 Tamże, s. 73.

${ }^{28}$ Suma danych procentowych wynika z płynności granic wyznaczonych kategorii. Złożona motywacja części jednostek leksykalnych spowodowała, że niektóre określenia zaklasyfikowano do dwu grup. O problemie granic i składu leksykalnego pola pisał Ryszard Tokarski, zob. tegoż, Światy za słowami. Wykłady z semantyki leksykalnej, Lublin 2013, s. 259-260; por. tenże, Stownictwo jako interpretacja..., s. 355. Przedstawione wyniki będą się oczywiście różnić w zależności od przyjętej przez badacza klasyfikacji, terenu badań czy liczby zgromadzonych jednostek leksykalnych. Niemniej jednak wydaje się, że stosunek ilościowy między poszczególnymi grupami nazw roślin może być zbliżony. Przypuszczenie to potwierdzają m.in. badania Ewy Rogowskiej-Cybulskiej. Badaczka wykazała, że nazwy roślin motywowane słownictwem religijnym zawarte w Słowniku gwar kaszubskich na tle kultury ludowej Bernarda Sychty stanowią ok. 5\% ogólnego zasobu fitonimicznego (ponad tysiąc jednostek leksykalnych). Zob. E. Rogowska-Cybulska, Nazwy roślin motywowane słownictwem religijnym ..., s. 125-126.

${ }^{29}$ Por. H. Kurek, Punkt widzenia w językowym obrazie świata społeczności wiejskiej, w: Punkt widzenia w języku i kulturze, red. J. Bartmiński, S. Niebrzegowska-Bartmińska, R. Nycz, Lublin 2004, s. 216; H. Kurek, Przemiany leksyki gwarowej..., s. 98. 
(podbiał pospolity, Tussilago farfara), Aronove "uxo (cantedeskia etiopska, Zantedeschia aethiopica), rzeczy, np. bućiki Matki B Busḱiyi (obuwik pospolity, Cypripedium calcedus), substancji, np. kryf Xrystusa (dziurawiec zwyczajny, Hypericum perforatum), itp. W procesie nominacji uwzględniono najpierw to, co wynika z percepcji zmysłowej - dostrzeżono wyróżniające się, nieprototypowe cechy fizyczne gatunku, dopiero później w nazwę wpisany został element kultury ludowej. W wymienionych przykładach sakronim stanowi wyłącznie element określający człon główny nazwy rośliny ${ }^{30}$.

Wiara chrześcijańska zajmuje niewątpliwie istotne miejsce w świadomości ludzi żyjących na wsi. Człowiek, „wierząc w ustanowiony ład i prawa boskie”, próbuje zatem thumaczyć rzeczywistość zgodnie z przyjętymi przez siebie wartościami ${ }^{31}$. Silne przywiązanie do religii odzwierciedlają nie tylko tradycja, lecz także gwarowe nazwy roślin ${ }^{32}$.

W zebranym słownictwie gwarowym pojawiają się jednostki leksykalne odnoszące się do Boga: $B^{u}$ oze ǰžyfko (bylica boże drzewko, Artemisia abrotanum), $B^{u}$ oze licko (podbiał pospolity, Tussilago farfara). Społeczność wiejska przez porównanie wybranego gatunku do istoty nadprzyrodzonej, której przypisuje się cechy niezwykłe, wykraczające poza ziemską codzienność, podkreśla tym samym wyjątkowość desygnatu, jego szczególne właściwości fizyczne, por. $B^{u}$ oze žžyfko růśńe v "ogrůtku / m"ocno påxńe / bo B"ogíym påxńe / tag iagby taiymńicům / i daie śe do źiź do bukikietův na Matke B"oskům Źiylnům // žžyfko bo pyvńe to ze pšypominå žžyvo ${ }^{i}$ ino mńyise ies; Büoze licko - bo viys / iag iez liźź na viesne to

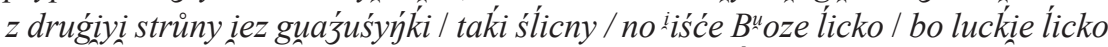
to iez rüzne né / må ṕieǵi må xrosty må to / a "ưn ies taki z víyrxu normalne źiylinny a püot spodym ies takim delikatnym vuosyckiym takim kutnyrym / ale ne cånkiym I ale takim guaźuńcim púokryty.

W hierarchii bytów Bóg stoi najwyżej, nie ingeruje jednak w ludzkie życie, pozostaje bierny, jego wolę wypełniają natomiast Chrystus, Matka Boska oraz święci, którzy pośredniczą między Stwórcą a człowiekiem. Ich imiona także zakrzepły w strukturze ludowych nazw roślin, por. kryf Xrystusa (dziurawiec zwyczajny, Hypericum perforatum), bućiki Matki B"oskiyi (obuwik pospolity, Cypripedium calcedus), uzy Matki B"osḱiyi (drżączka średnia, Briza media), vuoski Matki B"osḱiyi (wierzbówka kiprzyca, Chamaenerion angustifolium). Szczególnie odzwierciedla się w niniejszych jednostkach dyferencyjnych kult, jakim społeczność wiejska otacza Matkę Boską. Maryja jawi się jako istota

${ }^{30}$ Por. S. Niebrzegowska-Bartmińska, Sakronimy..., s. 282-283.

${ }^{31}$ A. Wierzbicka, Świat człowieka odzwierciedlony w fitonimach, w: Świat ukryty w stowach czyli o znaczeniu gramatycznym, leksykalnym i etymologicznym, red. I. Generowicz, E. Kaczmarska, I.M. Doliński, Warszawa 2009, s. 422.

32 Por. S. Niebrzegowska-Bartmińska, Sakronimy..., s. 281. 
piękna, doskonała, nieskazitelna (por. bućiki Matki B" oskkiyi bo sům iag maue bućiki / gådai⿱um ze to tylko Matka $B^{u}$ oskå mogua ino míyć; bo po tym iak pšekfítńe to må takí pínkne naśůnka / taki puseǵ iak" od mlyca dmuxåfca / ale takie uadne

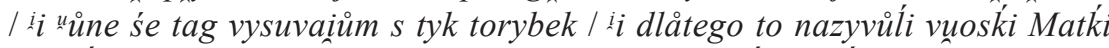
Buoskiyi), ale także przepełniona bólem (por. uzy Matki Bu oskiyi to tråva / bo må kuoski iag uzy Matki B" oskiyi ćyrṕi ioncyi). Męczeństwo Chrystusa oddaje nazwa dziurawca, z którego napar przypomina użytkownikom języka krew, por. to iez

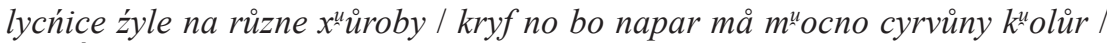
muvilíi ze míå u pu kšyzym růś / ii ta kryf co z boku Xrystusovego vypuynyua to polyćåua na ńe. Budowa gwarowych określeń roślin upamiętnia także świętych,

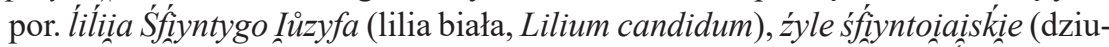
rawiec zwyczajny, Hypericum perforatum). I w tym wypadku podstawą nazwy jest składnik kategoryzujący, sakronim zaś pełni funkcję przydawki klasyfikującej, rodzajowej. Motywacja niniejszych nazw wskazuje ponadto na inny czynnik, który w akcie nominacji wziął pod uwagę podmiot mówiący, mianowicie czas

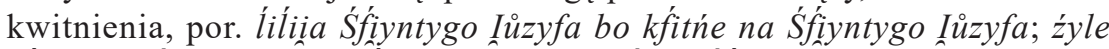
śf́iyntoiaiskie dlåtego ze kfitńe akurad v "okolicak Śf́ínntygo Iana.

W leksyce mieszkańców wsi pojawiły się nazwy roślin kojarzone z postaciami czy miejscami biblijnymi i związanymi z nimi historiami, np. Indåsove srybrńiki (miesięcznica roczna, Lunaria annua), Aronove "uxo (cantedeskia etiopska, Zantedeschia aethiopica), gvíiåzda betlyiymskå (wilczomlecz piękny, Euphorbia pulcherrima), trůmba ieryxůiskå (bieluń dziędzierzawa, Datura stramonium). W tworzonych przez społeczność nazwach gwarowych odzwierciedla się wyniesiona z Kościoła wiedza, która staje się podstawą tworzenia podań ludowych, legend, apokryfów, por. no iag Indåsove srybrńiki "okrůngue i $i$ srybrne / cymu Iudåsove / no byuo to tag ze Indåz rućyu srybrniki na źymíe / jyćüm

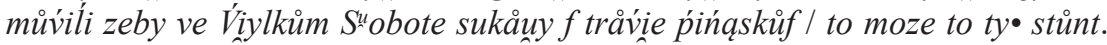
Eksplikacja nie zawsze jest dla informatorów prosta do sformułowania. Może to wynikać nie tyle z braku wyrazistości etymologicznej nazwy, ile z indywidualnego doświadczenia i wiedzy respondenta, np. o nazwie Aronove "uxo: bo takíie må iedno "uxo / ale Aronove "uxo to tylko tu zafse gådai i̊m stare bapki; trůmba ieryxůiskå bo to iez nåiviviygkså trůmba ieryxuisskå taka gžmi / a bo "ưn må takíe biåne trůmby / kielixy; bo to kštåntym to ia • gúiåadecka / to tyn co se na B"oze Narozyńe čsymå / bo to ta gådåli ze to ia • gúiåzda betlyiymskå. W strukturę nazw, które wiążą się z osobami boskimi, nie zawsze wpisany jest sakronim, por. totys (rdest plamisty, Polygonum persicaria). Jak wyjaśnia jedna z informatorek, iez lygynda ze iag zbiyrůli źyle śf́iyńcić to Matka B"oskà vźyna paluskami tyn

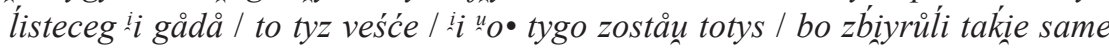
ślaxytne źůua a tygo ńe. Społeczność wiejska nie bez powodu snuje niezwykłe historie wokół postaci boskich, pozwalają one bowiem lepiej zrozumieć otaczającą człowieka rzeczywistość. 
Do kategorii nazw motywowanych względami religijnymi można także zaliczyć nazwę dusḱi (miechunka rozdęta, Physalis alkekengi). Jednostka ta odzwierciedla ludowe wierzenia $\mathrm{w}$ istnienie duszy oraz $\mathrm{w}$ życie pośmiertne, por. a bo to dlå du zanośyli na cmyntåš / "ůne takíe sům suxe to dugo śyzům.

Odniesienia do osób boskich czy świętych utrwalone w gwarowych nazwach roślin świadczą o silnym przywiązaniu wiejskiej wspólnoty językowo-kulturowej do religii katolickiej. Najliczniejszą grupę stanowią naturalnie określenia, w których strukturze zakrzepły postacie Boga oraz Matki Boskiej. Jej kult ma dla mieszkańców wsi szczególne znaczenie.

Niejednokrotnie podstawą w procesie nominacji stawały się właściwości magiczne gatunków botanicznych. „Do niedawna jeszcze kultury wiejskie cechowały się świadomością mityczno-magiczną. Była ona niejako nieodłączną częścią życia codziennego na wsi” ${ }^{3}$. Niezwykła „moc przypisywana roślinom wynikała z wierzeń odnoszących się do ich powstania, cech wyglądu, a wreszcie działania - leczniczego bądź trującego"34. W zebranym materiale pojawiają się jednak tylko cztery nazwy gwarowe związane z magią. Dawne rytuały zanikają bowiem pod wpływem kultury chrześcijańskiej. Analizowane słownictwo botaniczne świadczy mimo wszystko o szczególnej roli „wierzeń i praktyk magicznych w kulturze ludowej”, wypływających „ze sposobu wyjaśniania niezrozumiałych (a przez to budzących lęk) zjawisk przyrody, z przypisywania jej tajemnych sił, które oddziałują na człowieka i na jego najbliższe otoczenie"35.

W zebranym materiale pojawiają się nazwy utrwalające pozytywną moc danych gatunków botanicznych: క̌žyfko scyiśćå (grubosz jajowaty, Crassula opata), lubscek (lubczyk ogrodowy, Levisticum officinale) oraz ǰyvíyńćśiu (dziewięćsił pospolity, Carlina vulgaris). Rośliny, według ludności wiejskiej, przynoszą miłość, szczęście czy też wzmacniają organizm, por. lubsceg muvilí ze må puomagaź v miunostkak / lubsceg na lubíyńe / ale ile f tym pråvdy; vyglůndå íag žžyfko / íino mńyise / miååno davać scyiśće (eksplikacja nazwy žžyfko scyiśćca); jyyviyńćśiu / śiu / bo śiua / daie siune / pevne co tym lecyli.

Wśród odnotowanych gwarowych jednostek botanicznych odnaleźć można także określenie nadane roślinie o złych mocach, mianowicie ńytota (widłak goździsty, Lycopodium clavatum). Ze słowem tym wiąże się kwestia tabu, wynikająca z niebezpiecznych właściwości gatunku. Jak zaznacza Jadwiga

${ }^{33}$ J. Waniakowa, Pokrzyk wilcza jagoda - polskie nazwy gwarowe rośliny magicznej, w: Wręgu dialektów i folkloru. Prace ofiarowane Doktor Teresie Gołębiowskiej, Docent Wandzie Pomianowskiej i Docent Zofii Stamirowskiej, red. S. Cygan, Kielce 2007, s. 215.

34 Tamże, s. 215.

${ }^{35}$ J. Waniakowa, Polskie gwarowe nazwy..., s. 116; por. taż, Pokrzyk wilcza jagoda..., s. 216. 
Waniakowa, nie wypowiada się ,prawdziwej” nazwy rośliny, by nie przywołać $\mathrm{zlego}^{36}$, por. to ny ta ńytota / ne mưvyli " $\mathrm{n}$ ńyi / bo to ńyby caroźyiskie $m^{u}$ oce må.

Ludowe nazwy roślin motywowane magią i religią stanowią grupę nieliczną w stosunku do jednostek, których podstawą w procesie nominacji były wyłącznie rzadko spotykane, wyraziste cechy fizyczne desygnatów. Rzeczywistość pozajęzykowa jest odbierana za pomocą zmysłów, dlatego też człowiek, nazywając rośliny, bierze przede wszystkim pod uwagę kształt, barwę, jakość i smak rośliny. Dla mieszkańców wsi znaczenie mają również wartość użytkowa traw, ziół czy chwastów (przydatność w gospodarstwie, właściwości lecznicze), niekiedy czas kwitnienia, owocowania czy wysiewu roślin, ich miejsce występowania. Postrzeganie gatunków botanicznych jest uzależnione także - choć w mniejszym stopniu - od kultury społeczności wiejskiej, religii i magii. Nazwy zawierające sakronim świadczą o silnym przywiązaniu wiejskiej wspólnoty językowo-kulturowej do religii katolickiej ${ }^{37}$. W ludowych nazwach roślin utrwalona została również wiara w magiczną moc roślin, pozytywną oraz negatywną, należącą do sfery tabu. Gwarowe słownictwo botaniczne może pełnić tym samym funkcję ostrzegawczą, utrwalać zwyczaje czy wyrażać stosunek społeczności wiejskiej do danych osób lub obiektów.

Pojawienie się w leksyce gwarowej nazw roślin, w których odzwierciedla się pierwiastek zarówno chrześcijański, jak i pogański, świadczyć może o tym, że w kulturze ludowej religia i magia nie wykluczają się, lecz uzupełniają. Magia, mimo dominujących praktyk religijnych, nakazów i zakazów kościelnych, braku akceptacji dla wierzeń charakterystycznych dla kultury pierwotnej, przedchrześcijańskiej, istnieje ,jako coś oczywistego, niepodlegającego dyskusji, będącego częścią życia"38. Praktyki magiczne w żadnej mierze nie pomniejszają wartości i nie zubożają religijnego obrazu świata, który jest tak istotny dla wiejskiej wspólnoty językowo-kulturowej i głęboko w niej zakorzeniony. W kulturze ludowej elementy racjonale oraz irracjonalne współistnieją i odzwierciedla to doskonale język.

\section{Bibliografia}

Anusiewicz J., Lingwistyka kulturowa. Zarys problematyki, Wrocław 1995.

Bartmiński J., Styl potoczny, w: Encyklopedia kultury polskiej XX wieku, t. 2, Współczesny język polski, red. J. Bartmiński, Wrocław 1993.

${ }^{36}$ Por. taż, Polskie gwarowe nazwy..., s. 117.

${ }^{37}$ Por. np. A. Wierzbicka, Magia, wierzenia..., s. 367.

${ }^{38}$ Z. Mach, Obecność magii..., s. 7. 
Budziszewska W., Słowiańskie słownictwo dotyczace przyrody żywej, Wrocław 1965.

Budziszewska W., Wybrane nazwy roślin ze Szczawnicy i okolic, „Język Polski” 1985, z. 2-3.

Budziszewska W., Pierwiastek chrześcijański i pogański w polskiej terminologii botanicznej na tle słowiańskim, „Rozprawy Komisji Językowej Łódzkiego Towarzystwa Naukowego" 1986, t. 32.

Cienkowski W., Teoria etymologii ludowej, Warszawa 1972.

Dokulil M., Teoria derywacji, tłum. A. Bluszcz i J. Stachowski, Wrocław 1979.

Dubisz S., Kraś H., Kolis N., Dialekty i gwary polskie, Warszawa 1995.

Kurek H., Punkt widzenia w językowym obrazie świata społeczności wiejskiej, w: Punkt widzenia w języku i kulturze, red. J. Bartmiński, S. Niebrzegowska-Bartmińska, R. Nycz, Lublin 2004.

Kurek H., Przemiany leksyki gwarowej na Podkarpaciu, Kraków 2003.

Mach Z., Obecność magii (recenzja), w: D. Jaźwiecka-Bujalska, Między magia a religia, czyli zabobony i przesąy wśród duchowieństwa katolickiego we wspótczesnej Polsce, Kraków 2000.

Markowski A., Polszczyzna końca XX wieku, Warszawa 1992.

Mirek Z., Piękoś-Mirkowa H., Zając A., Zając M., Flowering Plants and Pteridophytes of Poland. A Checklist. Krytyczna lista roślin naczyniowych Polski, Kraków 2002.

Niebrzegowska-Bartmińska S., Sakronimy w polskim ludowym obrazie ziót, w: W świecie nazw. Księga jubileuszowa dedykowana Profesorowi Czesławowi Kosylowi, red. H. Pelcowa, Lublin 2010.

Pelcowa H., Nazwy roślin w świadomości językowej ludności wiejskiej, „Język a Kultura" 2000, t. 16: Świat roślin w języku i kulturze, red. A. Dąbrowska i I. Kamińska-Szmaj.

Pelcowa H., Językowy obraz roślin w gwarach Lubelszczyzny, w: Język polski. Współczesność. Historia, red. W. Książek-Bryłowa i H. Duda, Lublin 2002, t. 3.

Piechnik A., 2009, Wizerunek kobiety i mężczyzny w językowym obrazie świata ludności wiejskiej (na przykładzie gminy Zakliczyn nad Dunajcem), Kraków.

Rak M., Kwiatki Matki Bożej. Góralskie fitonimy odwotujące się do świętych i Matki Bożej, w: Turystyka religijna na obszarach górskich, red. A. Jackowski, F. Mróz, I. Hodorowicz, Nowy Targ 2009.

Rogowska-Cybulska E., Nazwy roślin motywowane stownictwem religijnym w ,Słowniku gwar kaszubskich” Bernarda Sychty, „Rocznik Gdański” 2004, t. 64, z. $1 / 2$.

Tokarski R., Stownictwo jako interpretacja świata, w: Encyklopedia kultury polskiej XX wieku, t. 2: Współczesny język polski, red. J. Bartmiński, Wrocław 1993. 
Tokarski R., Światy za słowami. Wykłady z semantyki leksykalnej, Lublin 2013.

Waniakowa J., Pokrzyk wilcza jagoda - polskie nazwy gwarowe rośliny magicznej, w: W kręgu dialektów i folkloru. Prace ofiarowane Doktor Teresie Gotębiowskiej, Docent Wandzie Pomianowskiej i Docent Zofii Stamirowskiej, red. S. Cygan, Kielce 2007.

Waniakowa J., Polskie gwarowe nazwy dziko rosnacych roślin zielnych na tle słowiańskim. Zagadnienia ogólne, Kraków 2012.

Wierzbicka A., Świat człowieka odzwierciedlony $w$ fitonimach, w: Świat ukryty w słowach, czyli o znaczeniu gramatycznym, leksykalnym i etymologicznym, red. I. Generowicz, E. Kaczmarska, I.M. Doliński, Warszawa 2009.

Wierzbicka A., Magia, wierzenia a gwarowe określenia roślin, „Rozprawy Komisji Językowej Łódzkiego Towarzystwa Naukowego” 2012, t. 58.

\section{Streszczenie \\ Motywy religijne i magiczne utrwalone w ludowych nazwach roślin (na przykładzie leksyki górali rabczańskich)}

Przedmiotem artykułu jest opis ludowych nazw roślin, w których strukturze utrwalone zostało słownictwo związane z religią i magią. Autorka podejmuje się także próby określenia relacji między pierwiastkiem chrześcijańskim a pogańskim. Zgromadzony materiał obejmuje słownictwo gwarowe mieszkańców kilku wsi podhalańskich. Biorąc pod uwagę eksplikacje respondentów, odnotowane nazwy ludowe przyporządkowano do czterech nadrzędnych kategorii: cechy fizyczne desygnatu, czas i miejsce wegetacji, wartość użytkowa oraz odniesienia kulturowe (religia i magia). Pozwoliło to wskazać, jaki procent ogólnego zasobu botanicznego stanowią nazwy roślin, na których powstanie wpłynęły wierzenia ludowe. W tekście opisano 18 gwarowych jednostek leksykalnych, pozwalających zrekonstruować ludową wizję świata, a także odkryć wartościowanie i sposób myślenia wspólnoty wiejskiej. Analiza wykazała, że postrzeganie gatunków botanicznych zależy w dużej mierze od społecznych ram kulturowych. Ludowe nazwy roślin, zawierające w swej strukturze sakronimy, np. Bóg, Chrystus, Matka Boska, świadczą o silnym przywiązaniu wiejskiej wspólnoty językowo-kulturowej do religii katolickiej. Słownictwo botaniczne dowodzi również, jak szczególna jest w kulturze ludowej rola wierzeń i praktyk magicznych. W zebranym materiale pojawiają się mimo to nieliczne nazwy roślin związane z magią. Dawne rytuały zanikają bowiem pod wpływem kultury chrześcijańskiej. Wydaje się jednak, że elementy racjonalne i irracjonalne w kulturze ludowej współistnieją i odzwierciedla je język. 


\section{Summary \\ The Religion and the Magic Set in Folk Plant Names (examples of the lexis of highlanders living near Rabka)}

The article deals with folk names of plant species, which are constituted by word and proper names typical of the religious and magical vocabulary. It addresses some problem of relation between pagan and Christian elements also. The analysis has been developed on the basis of the material collected in the several villages located in Podhale region. Category of the dialectal botanical lexis items was decided on the basis of the semantic motivation of names given by informers. All the collected folk plant names are included in four superior groups such as physical characteristics of the designate, time and place of vegetation, useful properties and cultural references - religion and magic. It allows to evaluate what percentage of the general phytonymic lexis are plant names motivated by folk beliefs. Moreover, the paper describes 18 dialectal plant names of species, in which the folk vision of the world, the way of thinking and the value of the rural community were set. The analysis indicates that the perception of botanical species depends on the culture of the rural community. The folk plant names containing the divine names or saints names, e.g. God, Christ, the Virgin Mary, confirm the strong attachment to the Catholic religion by the rural linguistic and cultural community. Furthermore, the folk botanical vocabulary points out the special role of beliefs and magical practices in folk culture. However, there are only a few names related to magic, because the rituals disappeared under the influence of Christian culture. Nevertheless, as it appears rational and irrational elements coexist and reveal in language. 